\title{
Seed Contamination Thresholds for Development of Carrot Bacterial Blight Caused by Xanthomonas campestris pv. carotae
}

\author{
K. C. Umesh, R. M. Davis, and R. L. Gilbertson, Department of Plant Pathology, University of California, Davis \\ 95616
}

\begin{abstract}
Umesh, K. C., Davis, R. M., and Gilbertson, R. L. 1998. Seed contamination thresholds for development of carrot bacterial blight caused by Xanthomonas campestris pv. carotae. Plant Dis. 82:1271-1275.

The relationship between levels of carrot (Daucus carota subsp. sativus) seed contamination with Xanthomonas campestris pv. carotae and (i) establishment of populations of X. campestris pv. carotae on carrot leaves and (ii) the incidence and severity of carrot bacterial blight was determined in field plots in Davis, California, in 1995 and 1996. Levels of seed contamination ranged from 0 to $1.5 \times 10^{5} \mathrm{CFU} / \mathrm{g}$ in 1995 and from 0 to $1.5 \times 10^{7} \mathrm{CFU} / \mathrm{g}$ in 1996 . Seed contamination levels were positively correlated with $X$. campestris pv. carotae populations detected on leaves and with the incidence and severity of carrot bacterial blight. The size of $X$. campestris pv. carotae populations on leaves was also directly related to disease incidence. In 1996, yields were significantly reduced in plots established with seed lots having the highest levels of $X$. campestris pv. carotae contamination. Under the conditions of this study (i.e., a location having low rainfall and relative humidity), the threshold of seed contamination for the establishment of $X$. campestris pv. carotae populations on leaves and for the development of carrot bacterial blight was unexpectedly high: $10^{4}$ to $10^{5} \mathrm{CFU} / \mathrm{g}$ of seed.
\end{abstract}

Bacterial leaf blight of carrots (Daucus carota subsp. sativus), caused by Xanthomonas campestris pv. carotae, is a common problem wherever carrots are grown and can reduce carrot yields and seed quality $(3,4,7,10,11,13-15)$. X. campestris pv. carotae is commonly seedborne $(1,6,8,9)$, and contaminated seed is an important inoculum source for development of bacterial blight in the field. Bacteria apparently penetrate the cotyledons through stomata during seed germination (2). However, little is known about the level of seed contamination that is needed to give rise to bacterial blight development in the field (9). The objectives of this study were (i) to determine the threshold of seed contamination by $X$. campestris pv. carotae needed to give rise to bacterial blight in sprinkler-irrigated carrots, (ii) to monitor populations of $X$. campestris pv. carotae on plants in field plots established with seed lots having different levels of $X$. campestris pv. carotae contamination, and (iii) to determine the effect of bacterial blight on carrot yield.

Corresponding author: R. L. Gilbertson

E-mail: rlgilbertson@ucdavis.edu

Present address of K. C. Umesh: California Department of Food and Agriculture, 1220 N Street, Room A-372, Sacramento, CA 95814.

Accepted for publication 4 August 1998.

Publication no. D-1998-0918-01R

(C) 1998 The American Phytopathological Society

\section{MATERIALS AND METHODS}

Establishment of contaminated seed lots. Commercial seed lots (cultivar SixPack) naturally contaminated with $X$. campestris pv. carotae were obtained, and levels of contamination in these lots were determined by the seed wash and dilution plating method described by Kuan et al. $(8,9)$ with slight modifications. Ten grams of seed from each lot was added to $100 \mathrm{ml}$ of $0.85 \% \mathrm{NaCl}$ in a $250-\mathrm{ml}$ Erlenmeyer flask, and flasks were kept at $4^{\circ} \mathrm{C}$ for 16 to $18 \mathrm{~h}$. Two drops of Tween 20 were added to the seed wash solution, and the flasks were placed on a rotary shaker at 250 RPM for 2 to $3 \mathrm{~min}$. The seed wash solution was filtered through cheesecloth into sterile 50$\mathrm{ml}$ polystyrene centrifuge tubes, and the tubes were centrifuged at $10,000 \times g$ for 10 min. The supernatant was decanted, and the pellet was resuspended in $10 \mathrm{ml}$ of $0.85 \% \mathrm{NaCl}$. Serial dilutions of this suspension (to $10^{-5}$ ) were prepared in $0.85 \%$ $\mathrm{NaCl}$, and $100-\mu \mathrm{l}$ aliquots of each dilution were spread onto each of three plates of XCS medium, a semi-selective medium for $X$. campestris pv. carotae $(8,9)$. After incubation at $28^{\circ} \mathrm{C}$ for 5 days, $X$. campestris pv. carotae colonies were counted. Each seed lot was assayed at least three times.

Seed lots having different levels of $X$. campestris pv. carotae contamination were prepared by mixing $X$. campestris pv. carotae-contaminated seed with clean seed in different proportions. The level of contamination in these seed lots was determined using the seed wash assay.
Pathogenicity tests. Selected strains of $X$. campestris pv. carotae from seed and plants were tested for pathogenicity in a greenhouse. Single colonies of the strain to be tested were inoculated into $100 \mathrm{ml}$ of nutrient broth in 250-ml flasks, and the flasks were placed on a shaker and incubated at $28^{\circ} \mathrm{C}$ for $24 \mathrm{~h}$. X. campestris pv. carotae cells were harvested from liquid cultures by centrifugation in $300-\mathrm{ml}$ polystyrene centrifuge tubes at $10,000 \times g$ for $10 \mathrm{~min}$. The pellet was resuspended in 0.01 $\mathrm{M}$ potassium phosphate buffer, $\mathrm{pH}$ 7.0, and the suspension was adjusted to approximately $10^{8}$ bacterial cells per ml. Carrot seedlings (30 to 35 days old) were sprayed with bacterial suspensions until runoff with a hand-held air pump sprayer (Airspray, Tech Spray Inc., Peachtree City, GA). The plants were placed in a greenhouse maintained at approximately $32^{\circ} \mathrm{C}$ and high humidity. At least four plants were inoculated with each $X$. campestris pv. carotae strain. The symptoms of bacterial blight developed on the leaves approximately 3 to 4 weeks after inoculation. $X$. campestris pv. carotae was reisolated from the symptomatic leaf tissues on 523 medium (5). Disease symptoms did not develop on control plants inoculated with phosphate buffer, nor was $X$. campestris pv. carotae isolated from these plants.

Establishment of experimental plots. Field plots were established at the University of California, Davis, Plant Pathology Experimental Farm on 28 June 1995 and 20 May 1996. For each year, a different site on the farm was used to establish the plots. Treatments consisted of four seed lots (A, B, C, and D), each with a different level of $X$. campestris pv. carotae contamination. In 1995, the A, B, C, and D lots had $0,1.5 \times 10^{1}, 1.5 \times 10^{3}$, and $1.5 \times 10^{5}$ $\mathrm{CFU}$ of $X$. campestris pv. carotae per $\mathrm{g}$, respectively. In 1996, the A, B, C, and D lots had $0,2.7 \times 10^{4}, 1.4 \times 10^{5}$, and $1.5 \times$ $10^{7} \mathrm{CFU} / \mathrm{g}$, respectively. The four treatments (seed lots A, B, C, and D) were replicated four times and planted in a randomized complete block design. Each replicate plot consisted of eight $80-\mathrm{cm}$ wide beds, $6 \mathrm{~m}$ long. Each bed was planted with two rows of carrots at a rate of 16 to 20 seeds per $30 \mathrm{~cm}$. The plots were sprinkler irrigated for about $1 \mathrm{~h}$ three times a week or every other day when the daytime temperature exceeded $38^{\circ} \mathrm{C}$. To prevent spread of the bacteria between plots during irrigation or by wind, eight 
rows of field corn were planted between plots, and $6 \mathrm{~m}$ of fallow ground was left on both sides of the corn.

Monitoring of $X$. campestris pv. carotae population on carrot leaves. Carrot seedlings emerged about 10 to 12 days after planting. Carrot plants were observed for development of bacterial blight symptoms beginning with emergence of true leaves and at 7-day intervals thereafter. Beginning 40 days after planting (DAP) and at 3-week intervals thereafter, leaves were sampled from each replicate plot to determine populations of $X$. campestris pv. carotae. Twenty leaves were collected at random from plants selected from a W pattern in the inner six beds of each replicate plot. Sampling was initiated in plot A and proceeded to plots $\mathrm{B}, \mathrm{C}$, and $\mathrm{D}$, respectively, to avoid spreading $X$. campestris pv. carotae among treatments. The fresh weight of the 20 leaves from each plot was determined, the leaves were cut into smaller pieces, and leaf tissue was placed in a $500-\mathrm{ml}$ flask containing $250 \mathrm{ml}$ of $0.01 \mathrm{M}$ phosphate buffer. The flasks were sonicated for $20 \mathrm{~min}$ in a sonicator (Ultrasonic FS-28, Fisher Scientific, Pittsburgh, PA). The leaf wash solution was then filtered through cheesecloth into 300$\mathrm{ml}$ polystyrene centrifuge tubes, and the tubes were centrifuged at $10,000 \times g$ for 10 min. The supernatant was decanted, and the pellet was resuspended in $10 \mathrm{ml}$ of 0.01 $\mathrm{M}$ phosphate buffer. Serial dilutions to $10^{-5}$ (early in the growing season) or to $10^{-12}$ (later in the growing season) were prepared in $0.01 \mathrm{M}$ phosphate buffer, and 100- $\mu \mathrm{l}$ aliquots were plated on XCS medium as described above for the seed wash assay. $X$. campestris pv. carotae colonies were counted after the plates were incubated at $28^{\circ} \mathrm{C}$ for 5 days.

Disease incidence and severity. Carrot plants were observed for development of bacterial blight symptoms beginning with emergence of true leaves, and at 7-day intervals thereafter, until harvest. Carrot bacterial blight incidence (percentage of plants showing disease symptoms) was determined by visually estimating the percentage of plants showing symptoms in each of the inner six rows of each replicate plot and calculating a mean disease incidence for each plot. Disease incidence was fitted to a logistic model, $Y=K / 1+B e^{-r t}$, where $Y$ is the disease incidence, $K$ is the maximum value of $Y$ observed in the field during that season, $B$ is the control parameter for value of $Y$ on day $0, r$ is the disease rate $(Y / 2$ at the inflection point of the curve), and $t$ is the time (days after planting minus 41). Forty-one days were subtracted from DAP because this was the time at which populations of $X$. campestris pv. carotae were first detected on leaves of
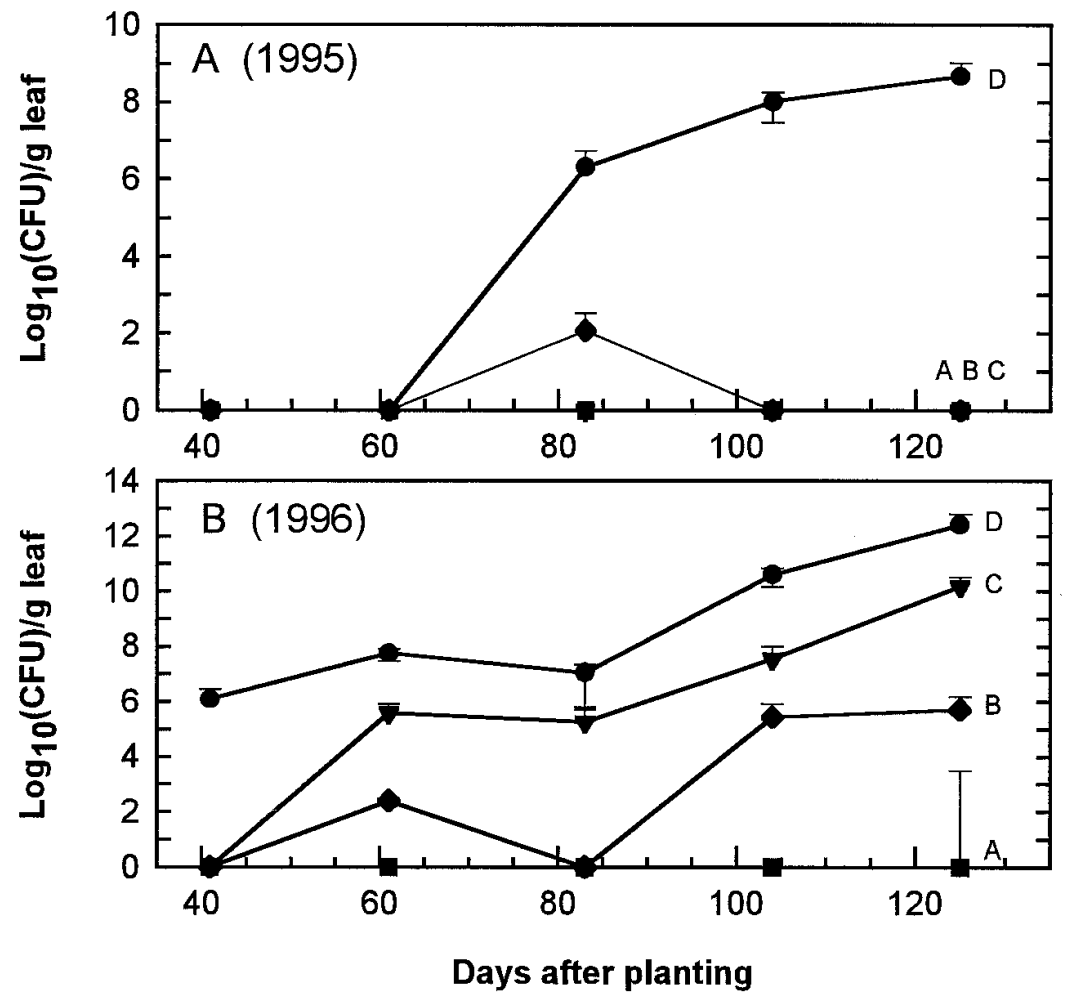

Fig. 1. Populations of Xanthomonas campestris pv. carotae recovered from carrot leaves in plots established with seed lots having different levels of $X$. campestris pv. carotae contamination. (A) Populations from the 1995 field experiment, and (B) populations from the 1996 field experiment. Each data point represents the mean of four replicate plots per seed lot. The levels of contamination of seed lots planted in 1995 were $\mathrm{A}=0, \mathrm{~B}=1.5 \times 10^{1}, \mathrm{C}=1.5 \times 10^{3}$, and $\mathrm{D}=1.5 \times 10^{5} \mathrm{X}$. campestris pv. carotae CFU/g. In 1996, the A, B, C, and D seed lots had $0,2.7 \times 10^{4}, 1.4 \times 10^{5}$, and $1.5 \times$ $10^{7} \mathrm{CFU} / \mathrm{g}$, respectively. carrots. The relationship of bacterial blight incidence to $X$. campestris pv. carotae leaf populations, determined at $125 \mathrm{DAP}$, was also fitted to a logistic model, $Y=K / 1+$ $B e^{-r p}$, where $p$ is the common $\log$ of the $\mathrm{CFU} / \mathrm{g}$ of leaf tissue.

Disease severity (percentage of leaf surface with bacterial blight symptoms) was determined using a rating scale of 1 to 6 , where $1=$ no symptoms, $2=1$ to $10 \%, 3=$ 11 to $20 \%, 4=21$ to $40 \%, 5=41$ to $60 \%$, and $6=>60 \%$ of the leaf with blight symptoms. On a 7-day interval from 104 DAP until harvest, disease severity was determined on each of 20 leaves randomly collected from the inner six beds of each replicate plot. A mean severity rating for each plot was determined from the ratings of the 20 leaves.

Determination of carrot yields. Carrots were harvested from a 2-m section of the two inner beds of each replicate plot at 135 and 128 DAP in 1995 and 1996, respectively. The leaves were removed from the roots, and the root fresh weight was determined for each replicate plot. The effect of the level of $X$. campestris pv. carotae seed contamination on carrot yield was analyzed by linear regression (12).

\section{RESULTS}

$X$. campestris pv. carotae populations. In the 1995 field experiment, populations of $X$. campestris pv. carotae were first recovered from carrot leaves in plots established with the most heavily contaminated seed lot (lot D, $1.5 \times 10^{5} \mathrm{CFU} / \mathrm{g}$ of seed) at 84 DAP (Fig. 1A). Populations on leaves in plots established with seed lot D increased from $2.0 \times 10^{6} \mathrm{CFU} / \mathrm{g}$ of leaf tissue at $84 \mathrm{DAP}$ to $4.7 \times 10^{8} \mathrm{CFU} / \mathrm{g}$ at 126 DAP. Populations of $X$. campestris pv. carotae were not recovered from leaves of carrots in plots established with seed lots A (0 CFU/g), B $\left(1.5 \times 10^{1} \mathrm{CFU} / \mathrm{g}\right)$, or C (1.5 $\left.\times 10^{3} \mathrm{CFU} / \mathrm{g}\right)$, except for one of the replicate plots of seed lot $\mathrm{B}$, in which a population of $4.7 \times 10^{3} \mathrm{CFU} / \mathrm{g}$ was detected at 84 DAP. However, $X$. campestris pv. carotae was not subsequently recovered from this plot.

In the 1996 field experiment, populations of $X$. campestris pv. carotae were first recovered from carrot leaves in plots established with seed lot D $\left(1.4 \times 10^{7}\right.$ CFU/g of seed) at 40 DAP (Fig. 1B). In plots established with seed lots B $(2.7 \times$ $10^{4} \mathrm{CFU} / \mathrm{g}$ of seed $)$ and $\mathrm{C}\left(1.4 \times 10^{5}\right.$ CFU/g of seed), X. campestris pv. carotae populations were recovered from carrot leaves at 61 DAP and at all samplings thereafter. $X$. campestris pv. carotae was not recovered from leaves of carrots in plots established with seed lot A (0 $\mathrm{CFU} / \mathrm{g}$ ), except for one of the replicate plots, in which $6.1 \times 10^{4} \mathrm{CFU} / \mathrm{g}$ of leaf tissue was detected at 125 DAP. In plots established with lot $\mathrm{D}$, populations on leaves increased from approximately $10^{6}$ CFU/g at 40 DAP to approximately $10^{12}$ 
CFU/g of leaf tissue at 125 DAP. In plots established with lots $\mathrm{B}$ and $\mathrm{C}$, populations reached approximately $10^{5} \mathrm{CFU} / \mathrm{g}$ and approximately $10^{10} \mathrm{CFU} / \mathrm{g}$, respectively, at 125 DAP (Fig. 1B).

In both 1995 and 1996, a number of representative $X$. campestris pv. carotae colonies recovered from leaves were tested for pathogenicity on carrot plants. In all cases, these strains induced carrot bacterial blight symptoms that were indistinguishable from those induced by a known $X$. campestris pv. carotae strain (Xcc 12). In addition, the identity of these and other X. campestris pv. carotae strains recovered from leaves was confirmed using polymerase chain reaction (PCR) with $X$. campestris pv. carotae- specific primers (13). For all putative $X$. campestris pv. carotae strains from leaves that were tested, these primers directed amplification of the expected DNA fragment (about $350 \mathrm{bp}$; data not shown).

Bacterial blight incidence and severity. In 1995, bacterial blight symptoms were first observed on plants in plots established with seed lot D at 95 DAP (Fig. 2A). Disease incidence in these plots was approximately $2 \%$ on day 95 and increased to approximately $11 \%$ by 131 DAP. No disease symptoms were observed on plants in plots established with seed lots A, B, and C. Due to the low level of disease that developed in 1995, disease severity was not recorded.
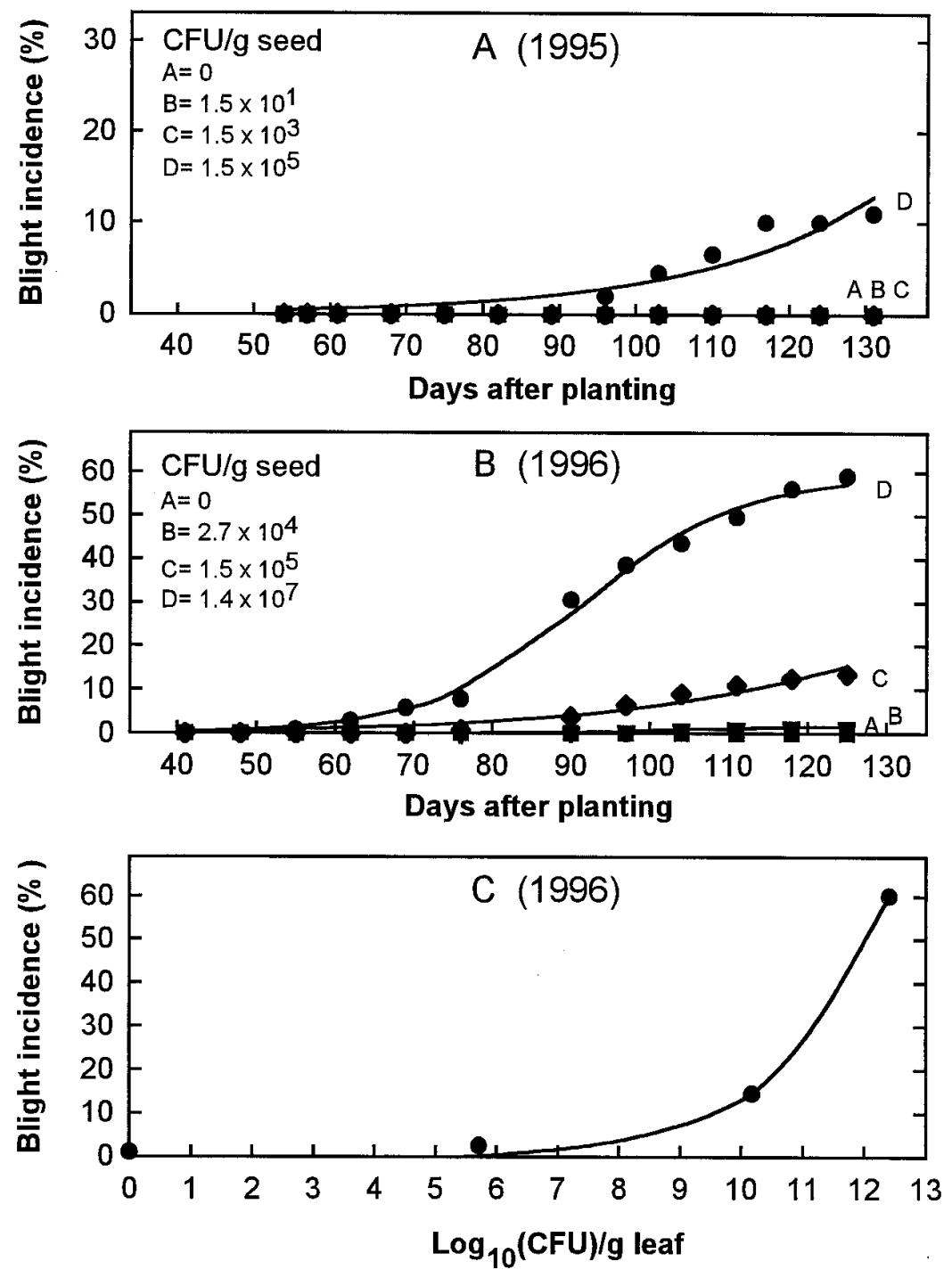

Fig. 2. Incidence of carrot bacterial blight in plots established with seed lots having different levels of Xanthomonas campestris pv. carotae contamination. (A) Disease incidence in the 1995 growing season, and (B) disease incidence in the 1996 growing season. The symbols represent means of four replicate plots per seed lot, and the lines are predicted disease progress curves according to the logistic model $Y=K / 1+B e^{-r t}$, where $Y$ is the disease incidence, $K$ is the maximum value of $Y$ as observed in the field during that season, $B$ is the control parameter for value of $Y$ on day $0, r$ is the disease rate (equals $Y / 2$ at the inflection point of the curve), and $t$ is the time (days after planting minus 41). (C) The relationship between bacterial blight incidence in 1996 and populations of X. campestris pv. carotae recovered from leaves in plots planted with seed lot $\mathrm{D}$ at $125 \mathrm{DAP}$. The logistic model $Y=$ $K / 1+B e^{-r p}$, with the predicted values $r=0.97, B=114007$, and $K=100$ for the parameters in the model, accounted for $95 \%$ of the variation in blight incidence.

In 1996, bacterial blight symptoms were first observed on plants in plots established with seed lot D at $55 \mathrm{DAP}$ and on plants in plots established with seed lots $\mathrm{B}$ and $\mathrm{C}$ at 76 DAP and 90 DAP, respectively (Fig. 2B). In plots established with seed lot D, the incidence of blight increased from $<1 \%$ at 55 DAP to approximately $59 \%$ by 125 DAP (Fig. 2B). In plots established with seed lots $\mathrm{B}$ and $\mathrm{C}$, the disease incidence increased to 1.5 and $13.5 \%$, respectively, by 125 DAP. No disease symptoms were observed on plants in plots established with seed lot A. Bacterial blight incidence at different times during the growing season was fitted to a logistic model, $Y=K / 1$ $+B e^{-r t}$, which accounted for $>95 \%$ of the variability in disease incidence. The predicted values of these parameters for the different treatments in 1996 were $K=$ 59.17 for all four treatments and $B=$ 234,802, 1,166, 117, and 156 for plots established with seed lots A, B, C, and D, respectively. The predicted values for disease rate, $r$, were $-2.01,0.043,0.044$, and 0.100 for plots established with seed lots A, B, C, and D, respectively. The incidence of bacterial blight and its relationship to the population of $X$. campestris pv. carotae on leaves was explained by the logistic model $Y=K / 1+B e^{-r p}$; the predicted values for the parameters in the model were $r=$ $0.97, B=114,007, K=100$, and $R^{2}=0.95$ (Fig. 2C).

Bacterial blight severity ranged from a mean of 1.0 (no disease) in plots established with seed lot A, to 3.8 in plots established with seed lot D. In plots established with lot D, disease severity increased from 3.4 at 104 DAP to 3.8 at 125 DAP (Fig. 3). In plots established with seed lot B, disease severity was only 1.1 at 125 DAP; whereas in plots established with seed lot $\mathrm{C}$, disease severity

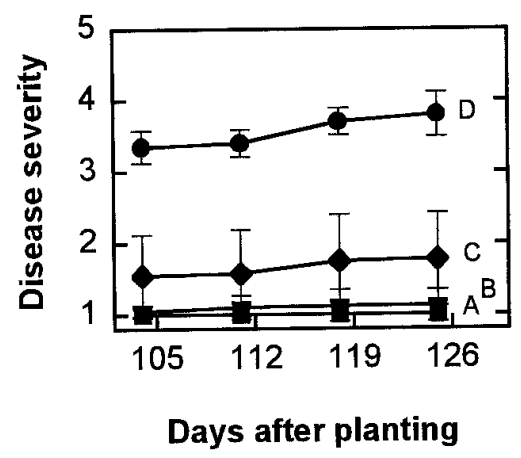

Fig. 3. Severity of carrot bacterial blight in plots established with seed lots having Xanthomonas campestris pv. carotae contamination levels of $0(\mathrm{~A}), 2.7 \times 10^{4}(\mathrm{~B}), 1.4 \times 10^{5}(\mathrm{C})$, and $1.5 \times 10^{7}$ (D) $\mathrm{CFU} / \mathrm{g}$. Disease severity was determined based on a rating scale of 1 to 6 , with $1=$ no symptoms, $2=1$ to $10 \%, 3=11$ to $20 \%, 4=21$ to $40 \%, 5=41$ to $60 \%$, and $6=$ $>60 \%$ of the leaf having blight symptoms. The data presented are for the 1996 field experiment and are the mean ratings of 20 leaf samples from each of four replicate plots per seed lot. 
increased from 1.6 at 104 DAP to 1.8 at 125 DAP.

Effect of seed contamination on carrot yield. In 1995, carrot yields from plots established with the four seed lots were not significantly different (Fig. 4A). In 1996, carrot yields were reduced in plots established with seed infested with $2.7 \times 10^{4}$, $1.4 \times 10^{5}$, and $1.5 \times 10^{7} \mathrm{CFU}$ of $X$. campestris pv. carotae per g (Fig. 4B). The 1996 yield data were fitted to the model $Y$ $=65.2-1.23\left[\log _{10}(\mathrm{CFU} / \mathrm{g}\right.$ of seed $\left.)\right],\left(R^{2}=\right.$ $0.95)$.

\section{DISCUSSION}

$X$. campestris pv. carotae is a ubiquitous seedborne pathogen of carrot, and bacterial blight can be found worldwide wherever carrots are grown (3,4,7,10,11,13-15). Disease development is highly dependent on environmental factors, and once established, it is difficult to manage. Thus, the use of pathogen-free seed is an important management strategy. Although hot water treatment can greatly reduce contamination of carrot seed by $X$. campestris pv. carotae (6), this method may not eradicate the pathogen entirely and may reduce seed germination. Furthermore, the sensitivity of seed wash assays used for detection of $X$. campestris pv. carotae is approximately $10^{2} \mathrm{CFU} / \mathrm{g}$ of seed. Thus, there is considerable interest in determining the threshold
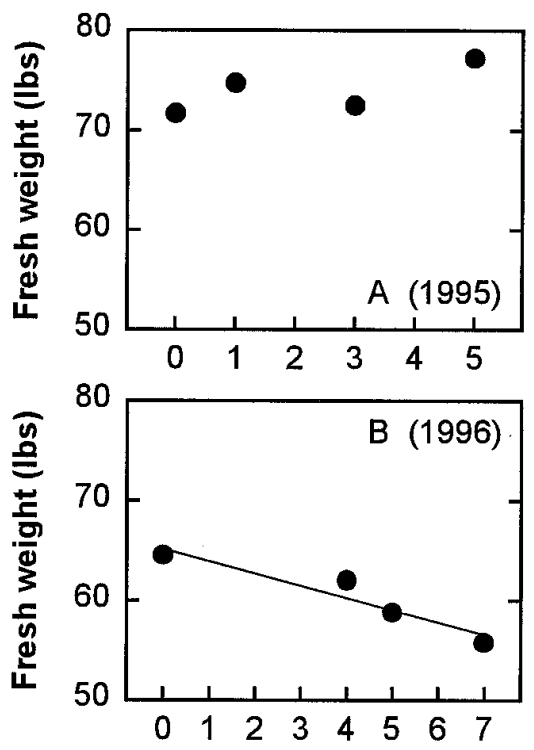

$\log _{10}$ (CFU/g seed)

Fig. 4. Carrot yields from plots established with seed lots having different levels of Xanthomonas campestris pv. carotae contamination. (A) 1995 field experiment, and (B) 1996 field experiment. For the 1996 experiment, the linear model $Y=65.2-1.23\left[\log _{10}(\mathrm{CFU} / \mathrm{g}\right.$ of seed $\left.)\right]$ accounted for $95 \%$ of the variability in yield with increasing levels of $X$. campestris pv. carotae seed contamination. In 1995, there was no relationship between levels of seed contamination and carrot yields. of seed contamination needed to give rise to bacterial blight epidemics in the field as well as the actual effect of the disease on carrot yield.

In this study, these questions were addressed through the establishment of field plots with carrot seed lots having different levels of seed contamination. X. campestris pv. carotae populations on leaves, bacterial blight development, and carrot yields were then determined for these plots. The seed contamination levels used in 1995 ranged from $0 \mathrm{CFU} / \mathrm{g}$ to what was considered a heavily contaminated seed lot $\left(1.5 \times 10^{5}\right.$ $\mathrm{CFU} / \mathrm{g}$ ). However, because relatively little bacterial blight developed in 1995, even in plots established with the heavily contaminated seed lot, two changes were made in 1996. First, the field plots were established 5 weeks earlier (28 June 1995 versus 20 May 1996), and second, a seed lot having a higher level of contamination $\left(1.5 \times 10^{7}\right.$ $\mathrm{CFU} / \mathrm{g}$ ) was used. More disease developed in 1996, but only in plots established with the seed lot having the highest level of contamination. Similar disease incidences (11\% in 1995 and $13.5 \%$ in 1996) developed in the plots established with seed lots having approximately $10^{5} \mathrm{CFU} / \mathrm{g}$ of seed. Thus, the increased disease incidence observed in 1996 appeared to relate more to the higher level of seed contamination than to the difference in planting date. Under the conditions of this study, the threshold of seed contamination needed to give rise to bacterial blight disease was $10^{4}$ to $10^{5}$ CFU/g of seed, which was unexpectedly high. This probably can be attributed, at least in part, to the fact that there is little rainfall and low humidity in this region (the Central Valley of California) during this time of the year.

$X$. campestris pv. carotae populations on carrot leaves were monitored to provide insight into the relationship between seed contamination levels and bacterial colonization of carrot leaves, and to assess whether this information could be used as a predictor of disease development. The seed contamination threshold for the establishment of populations on carrot leaves was also relatively high, in the range of $10^{4}$ to $10^{5} \mathrm{CFU} / \mathrm{g}$. $X$. campestris pv. carotae populations on leaves generally reflected levels of seed contamination because populations (i) were first detected in plots established with the most heavily contaminated seed lots and (ii) were positively correlated with seed contamination levels and the incidence of bacterial blight. The conditions for development of the bacterial populations on leaves appeared to be more favorable in 1996 than in 1995, because populations were detected on leaves 40 to 60 DAP in 1996 versus 84 DAP in 1995. The more conducive conditions in 1996 may have been due to environmental factors. In 1996, plots were established in the beginning of May, when the day temperatures were about $28^{\circ} \mathrm{C}$, and subsequent temperatures ranged from 25 to $35^{\circ} \mathrm{C}$ for most of the growing season. In 1995 , plots were established in late June, when the daytime temperatures were $>40^{\circ} \mathrm{C}$. Pfleger et al. (10) and Saad and Wade (11) reported that the optimum temperature for bacterial blight development was between 25 and $30^{\circ} \mathrm{C}$. In 1996 , it is possible that the level of seed contamination needed for establishment of $X$. campestris pv. carotae populations on leaves might have been lower than $10^{4} \mathrm{CFU} / \mathrm{g}$ (the lot having the lowest contamination rate), but this still would have been below the threshold for development of a significant level of disease.

In 1996, bacterial blight significantly reduced the fresh weight of carrot roots, which was probably due to a reduction in leaf area available for photosynthesis in diseased plants. These results establish that this disease can cause yield losses and suggest that the development of effective disease management strategies is warranted. Moreover, the extent of yield losses estimated in this study may have been underestimated because carrot roots were dug instead of being pulled by their leaf petioles as is done commercially by mechanical harvesters.

Thus, under the conditions of this study, the threshold of seed contamination for development of carrot bacterial blight was approximately $10^{4} \mathrm{CFU} / \mathrm{g}$ of seed; whereas the threshold for development of a disease epidemic (i.e., levels at which yield reductions occurred) was approximately $10^{5}$ $\mathrm{CFU} / \mathrm{g}$ of seed. Here, it is important to emphasize that these relatively high threshold levels may not be applicable to carrot growing regions having high rainfall and humidity (e.g., the eastern United States) or where different agronomic practices are used (e.g., higher seeding rates). In such situations, lower levels of seed contamination may give rise to populations of $X$. campestris pv. carotae on leaves that, under favorable conditions, could increase rapidly and cause significant levels of disease. However, our results do suggest that seed wash assays currently used to index carrot seeds for $X$. campestris pv. carotae, which detect $\geq 10^{2} \mathrm{CFU} / \mathrm{g}$ of seed, are probably sufficiently sensitive to indicate that a given seed lot is below the contamination threshold for development of a bacterial blight epidemic. Thus, growers should use seed lots that have been indexed and/or treated for $X$. campestris pv. carotae contamination in order to avoid risks of disease development under conducive conditions.

\section{ACKNOWLEDGMENTS}

This study was partially supported by grants from the California Fresh Carrot Advisory Board and the American Flower and Vegetable Seeds Research Foundation. We thank Robert Venette for his assistance in statistical analysis and development of logistic models to fit the data, and Lauren Franssen and Thomas Kominek for excellent technical assistance. 
LITERATURE CITED

1. Ark, P. A., and Gardner, M. W. 1944. Carrot bacterial blight as it affects the roots. Phytopathology 34:416-420.

2. Baker, K. F. 1972. Seed pathology. Pages 318416 in: Seed Biology. T. T. Kozlowski, ed. Academic Press, New York.

3. Blodgett, E. C. 1944. Carrot diseases in Idaho in 1943. Plant Dis. Rep. 28:764-769.

4. Chupp, C., and Sherf, A. F. 1960. Vegetable Diseases and Their Control. Ronald Press Company, New York.

5. Kado, C. I., and Heskett, M. G. 1970. Selective media for isolation of Agrobacterium, Corynebacterium, Erwinia, Pseudomonas, and Xanthomonas. Phytopathology 60:969976.
6. Kendrick, J. B. 1934. Bacterial blight of carrot. J. Agric. Res. 49:493-510.

7. Kenknight, G., and Blodgett, E. C. 1945. A survey of the diseases of the carrot seed crop in Idaho with control recommendations. Idaho Agric. Exp. Stn. Bull. 262:23

8. Kuan, T.-L., Minsavage, G. V., and Gabrielson, R. L. 1984. Detection of Xanthomonas campestris pv. carotae in carrot seed. (Abstr.) Phytopathology 74:796.

9. Kuan, T.-L., Minsavage, G. V., and Gabrielson, R. L. 1985. Detection of Xanthomonas campestris pv. carotae in carrot seed. Plant Dis. 69:758-760.

10. Pfleger, F. L., Harman, G. E., and Marx, G. A. 1974. Bacterial blight of carrots: Interaction of temperature, light, and inoculum proce- dures on disease development of various carrot cultivars. Phytopathology 64:746-749.

11. Saad, S. M., and Wade, E. K. 1972. Bacterial blight of carrot in Wisconsin. Plant Dis. Rep. 56:744-746.

12. SAS Institute. 1988. SAS/STAT Users Guide, Rel. 6.03 ed. SAS Institute, Cary, NC.

13. Umesh, K. C., Davis, R. M., and Gilbertson, R. L. 1996. Seed contamination thresholds associated with occurrence of bacterial blight of carrots and development of a DNA based detection method for Xanthomonas campestris pv. carotae. (Abstr.) Phytopathology 86:S11.

14. Walker, J. C. 1952. Diseases of Vegetable Crops. McGraw-Hill, New York.

15. Watson, R. D. 1948. Carrot bacterial blight control in Idaho. Plant Dis. Rep. 32:238-239. 